\title{
Effect of biostimulation on biodegradation of dissolved organic carbon in biological filters
}

\author{
K. Tihomirova, A. Briedis, J. Rubulis, and T. Juhna \\ Department of Water Engineering and Technology, Riga Technical University, Azenes street 16/20-263, \\ LV-1048, Riga, Latvia \\ Correspondence to: K. Tihomirova (kristina.tihomirova@ rtu.lv)
}

Received: 23 February 2012 - Published in Drink. Water Eng. Sci. Discuss.: 20 March 2012

Revised: 15 June 2012 - Accepted: 18 June 2012 - Published: 10 July 2012

\begin{abstract}
The addition of labile organic carbon (LOC) to enhance the biodegradation rate of dissolved organic carbon (DOC) in biological columns was studied. Acetate standard solution (NaAc) and Luria Bertrani (LB) medium were used as LOC as biostimulants in glass column system used for measurements of biodegradable dissolved organic carbon (BDOC). The addition of LOC related with the increase of total DOC in sample. The concentration of BDOC increased up to 7 and 5 times and was utilized after 24 min. contact time. The biodegradation rate constant was increased at least 26 times during adaptation-biostimulation period. There was a strong positive correlation between the biodegradation rate constant and the concentration of BDOC. Biostimulation period ranged from 24 to $53 \mathrm{~h}$ for NaAc biostimulant and from 20 to $168 \mathrm{~h}$ for LB. The study has shown that LOC could be used as stimulator to enhance the biodegradation rate of DOC during biofiltration.
\end{abstract}

\section{Introduction}

During ozonation dissolved organic carbon (DOC) is transformed to biodegradable organic carbon (BDOC), which then is metabolized by bacteria in the biofilter (Fahmi et al., 2003; Hammes and Vital, 2008; Volk et al., 1993). The amount of BDOC fraction depends on the type of natural organic matter (NOM) present in the water (Huck, 1990; Kaplan et al., 1994). The NOM compounds have different biodegradation kinetics: (i) fast biodegradable, (ii) more resistant to biodegradation or slow biodegradable and (iii) not biodegradable (Carlson and Amy, 2001; Klevens et al., 1996; Yavich et al., 2004). About $30 \%$ of DOC is usually removed after biofiltration (Volk et al., 2002) which are usually designed for empty bed contact time (EBCT) of less than $30 \mathrm{~min}$. In Boreal regions, where the surface waters contain high concentrations of NOM or organic matter substances having a low biodegradation rate and biofilters are operated at low temperatures, NOM removal in biofilter is not effective, and can reach only $15-19 \%$ measured as DOC, or $75 \%$ measured as neutral fraction or fast biodegradable part of NOM (Tihomirova, 2011). The slow biodegradable part of BDOC which is not removed in the biofilter will enter the distribution network and will be used as a substrate for bacteria (Eikebrokk et al., 2007; Tihomirova, 2011). To increase the biodegradation rate for removal of recalcitrant organic substances the addition of labile organic carbon (LOC) is a widely used practice for the remediation of contaminated soils, sediments and sewage (Brandt et al., 2003; Shimp and Pfaender, 1985; Spain et al., 1980; Wiggins and Alexander, 1988), however applicability of this approach for the removal of compounds resistant to biodegradation from drinking water during biofiltration has not yet been studied.

The aim of this paper was to evaluate the effect of addition of LOC in water to enhance the biodegradation rate of DOC during biofiltration.

Biostimulation effect was determined using bioreactor setup used to measure BDOC (Eikebrokk et al., 2007) and developed within the EU project TECHNEAU, which yields information not only on final concentrations of BDOC but also on the degradation kinetics. The study was carried out in a laboratory scale using treated humic rich water after biofilters. 


\section{Materials and methods}

\subsection{Glassware}

All glassware used in these experiments were cleaned thoroughly with a $10 \%$ solution of potassium dichromate in concentrated sulphuric acid and rinsed with ultra pure water (Elga PureLab Ultra, Veolia Water Ltd., UK), dried and covered with aluminium septum heated for $6 \mathrm{~h}$ at $+250^{\circ} \mathrm{C}$ in order to avoid organic carbon release (Van der Kooij et al., 1982).

\subsection{Reagents}

Acetate stock solution (NaAc) with concentration $\gamma$ $(\mathrm{DOC})=1 \mathrm{gl}^{-1}$, was made in a $1000 \mathrm{ml}$ volumetric flask where $5.6648 \mathrm{~g}$ of sodium acetate trihidrate $\left(\mathrm{CH}_{3} \mathrm{COONa} \cdot 3 \mathrm{H}_{2} \mathrm{O}\right.$, Ultra, $\geq 99.5 \%$, Fluka, Germany) was dissolved and made up to volume with water. The solution is stable at $4{ }^{\circ} \mathrm{C}$ for about 6 months.

Luria Bertani (LB) medium stock solution with concentration $\gamma(\mathrm{DOC})=7.5 \mathrm{~g} \mathrm{l}^{-1}$, was made in a $1000 \mathrm{ml}$ volumetric flask where LB medium contains $10 \mathrm{~g}$ Peptone, $5 \mathrm{~g}$ Yeast extract, $10 \mathrm{~g} \mathrm{NaCl}$ in $1000 \mathrm{ml}$ sterile ultra pure water. Both mentioned solutions were used as LOC for the biostimulation experiments.

To avoid inorganic nutrient limitation all samples $(100 \mathrm{ml})$ were supplemented with $100 \mu \mathrm{l}$ solution of inorganic nutrients. The solution was prepared by dissolving $4.55 \mathrm{~g}$ $\left(\mathrm{NH}_{4}\right)_{2} \mathrm{SO}_{4}, \quad 0.2 \mathrm{~g} \quad \mathrm{KH}_{2} \mathrm{PO}_{4}, 0.1 \mathrm{~g} \quad \mathrm{MgSO}_{4} \cdot 7 \mathrm{H}_{2} \mathrm{O}, 0.1 \mathrm{~g}$ $\mathrm{CaCl}_{2} \cdot 2 \mathrm{H}_{2} \mathrm{O}$ and $0.2 \mathrm{~g} \mathrm{NaCl}$ in sterile ultra pure water $(1000 \mathrm{ml})$ (Miettinen et al., 1999).

\subsection{DOC determination}

The concentrations of DOC were measured with a TOC5000A Analyzer (Shimadzu Corporation, Kyoto, Japan) according to European Standard EN 1484:1997. The $0.45 \mu \mathrm{m}$ pore size membrane filters (Millipore Corporation, USA or Sartorius AG, Germany) used for DOC measurements were carefully rinsed, first with ultra pure water and then with the water sample. The blank and control solution were analyzed with each series of DOC sample in order to verify the accuracy of the results obtained by the method. Every DOC sample was tested in duplicate and the mean values were calculated (instrumental relative standard deviation $(\mathrm{CV}) \leq 2 \%$ ).

\subsection{Study site}

The experiments were done using water samples taken after passing through biologically activated carbon (BAC) filters from the surface water treatment plant (WTP) in Riga, Latvia. The raw water in River Daugava contains $15.34 \pm 3.84 \mathrm{mg} \mathrm{l}^{-1}$ of DOC and is treated conventionally by coagulation-sedimentation and filtration in rapid sand filters.
Then the water is ozonated and filtrated through the BAC filters. Water after biofilter contains $5.33 \pm 1.45 \mathrm{mg} \mathrm{l}^{-1}$ of DOC (Tihomirova et al., 2010).

The BAC samples were taken without strict frequency over the period of $1 \mathrm{yr}$. In total 30 experiments were carried out in this study.

\subsection{Experimental design and sampling procedure}

All water samples $(2000 \mathrm{ml})$ from BAC filtration were collected in glass bottles completely filled with the sample and subsamples $(50 \mathrm{ml})$ from glass column system were collected in sterile glass bottles and stored in a refrigerator at temperature in the range of 2 to $5^{\circ} \mathrm{C}$, before the analyses were done.

To evaluate the effect of addition of LOC on biodegradation the BDOC experimental set-up contains several chromatography glass columns with different height $(H$, from 5 to $25 \mathrm{~cm}$ ) (Chromaflex, USA) coupled in-series system (Fig. 1), which was filled with glass carrier beads $(\varnothing=6 \mathrm{~mm}$, specific surface area $=3.76 \mathrm{~cm}^{2} \mathrm{~g}^{-1}$ ) as a support media for bacteria (Eikebrokk et al., 2007) was used.

The EBCTs in system was $272 \mathrm{~min}$. The samples were continuously pumped upward the columns using a peristaltic pump (Masterflex L/S, Cole-Parmer, USA). An optimal flow rate of $2-5 \mathrm{ml} \mathrm{min}^{-1}$ was used. The biodegradation kinetics of the sample was measured using the intermediate samples (i.e. EBCTs with 8 min intervals).

The biomass in all the columns was kept constant by the homogenization after each experiment. The glass beads were removed from the columns and homogenized by shaking for $24 \mathrm{~h}$ and reused after. The biomass concentration

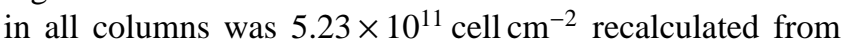
adenosine 5-triphosphate (ATP) measurements, according to Magic-Knezev and Van der Kooij (2004).

\subsection{Determination of biomass concentration}

The concentration of biomass in the column system was measured as the concentration of ATP. The total ATP concentration was determined as described by Berney et al. (2006) using the Promega Bac Titer-Glo Microbial Cell Viability Assay (Promega Corporation, USA) and the calculations were based on the standard curve made with known ATP standard dilutions (Promega Corporation, USA) in sterile ultra pure water. The measurements of ATP were made in the solution obtained from $5 \mathrm{~g}$ of glass beads from each column collected in a sterile plastic tube filled with $25 \mu \mathrm{l}$ ultra pure water and treated by sonification for 2 min with $40 \%$ amplitude or $115 \mathrm{~J}$ of energy (Ultra Sonic processor, Cole Parmer, USA) and in the effluent water after each column during the sampling process for DOC samples. The bacterial ATP was calculated by subtracting the extracellular ATP from the total ATP (Hammes and Vital, 2008). The luminescence was measured as an integral over $10 \mathrm{~s}$ in relative light units (RLU) 


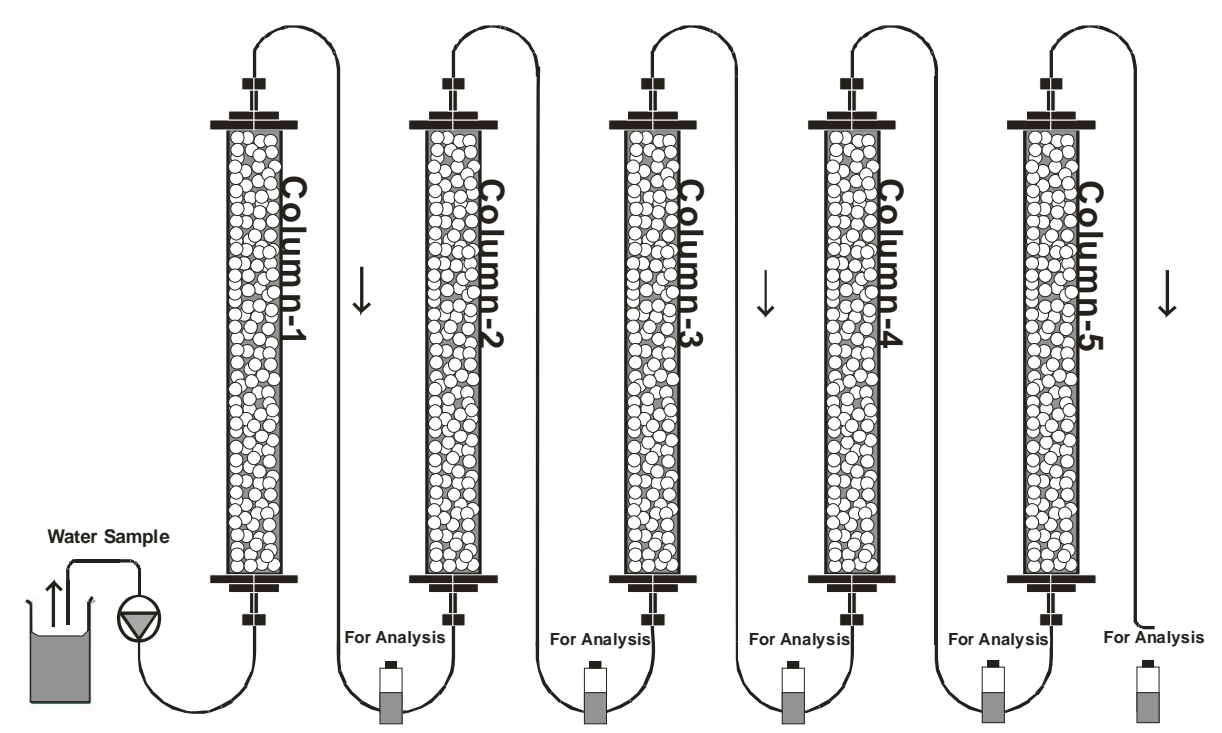

Figure 1. BDOC experimental set-up (adapted from Tihomirova, 2011).

using a luminometer (Hygiene International, Pi-102, Germany). All the samples were measured in triplicate.

\subsection{Calculations}

The $k$ degradation rate was obtained by fitting the experimental data to the exponential function and expressed as first order kinetic constant $\left(\mathrm{min}^{-1}\right)$. The equation was fitted separately to data for period in which the minimum concentration of DOC or maximum concentration of BDOC was reached. The regression coefficients $\left(R^{2}\right)$ for exponential curve and Pearson criteria $(P)$ were used (Microsoft Office Excel, 2003). To compare the degradation rate values of statistically significant assays the Moment correlation coefficient $(r)$ was used (Fower et al., 1998).

\section{Results}

To stimulate biodegradation rate of slowly degradable part of DOC in drinking water treatment the effect of addition of LOC (NaAc or LB) in water was tested in the glass column system.

The average concentration of BDOC of water sample from BAC without addition of LOC was only $0.49 \pm 0.29 \mathrm{mg} \mathrm{l}^{-1}$ $(n=14)$ or $7 \%$ of $\mathrm{DOC}_{\mathrm{BAC}}$ in this study. The biodegradation rates constant $(k)$ of BDOC in BAC water samples with $\mathrm{NaAc}$ and $\mathrm{LB}$ as biostimulants were higher (about $4.16 \times 10^{-2}$ and $2.57 \times 10^{-2} \mathrm{~min}^{-1}$, respectively), whereas the biodegradation rate in the sample without biostimulant was one order of magnitude lower $\left(0.10 \times 10^{-2} \mathrm{~min}^{-1}\right)$, see Fig. 2 . The biodegradation rates in the samples with $\mathrm{NaAc}$ and $\mathrm{LB}$ as biostimulant were at least 26 times higher compared with the BAC sample without biostimulant.

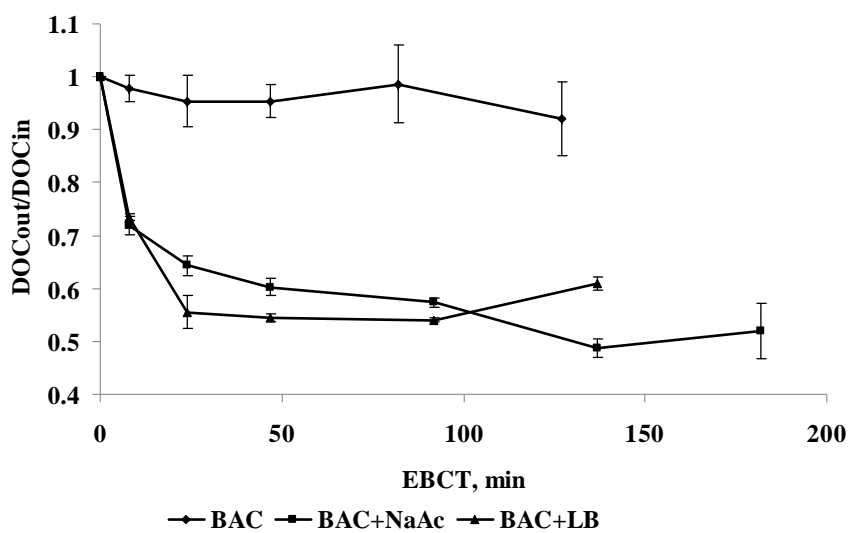

Figure 2. Average DOC changes versus EBCT (adapted from Tihomirova, 2011). Legends: water sample after biofilters from Daugava WTP (BAC, $n=14$ ); water sample after biofilters from Daugava WTP with biostimulant sodium acetate after $30 \mathrm{~h}$ feeding $(\mathrm{BAC}+\mathrm{NaAc} ; n=3)$ and with Luria Bertrani broth after $48 \mathrm{~h}$ feeding $(\mathrm{BAC}+\mathrm{LB} ; n=3)$, respectively.

Traditionally the concentrations of BDOC analysed with dynamic method in glass column system with attached biofilm were calculated as the difference in concentration of DOC between the inlet water sample in column system and the effluent water sample with lowest concentration of DOC, namely $\mathrm{DOC}_{\mathrm{BAC}}$ and $\mathrm{DOC}_{\text {min }}$ (Fig. 3) based on the definitions developed by other researchers (Fahmi et al., 2003; Hammes and Vital, 2008; Volk et al., 1993; Ribas et al., 1991 and Yavich et al., 2004) and in this study called $\mathrm{BDOC}_{\mathrm{BAC}}$. The total concentration of BDOC (namely $\mathrm{BDOC}_{\text {total }}$ ) which accounts for both parts - quantity of biodegradable part in sample $\left(\mathrm{DOC}_{\mathrm{BAC}}\right)$ and $\mathrm{LOC}\left(\mathrm{DOC}_{\mathrm{LOC}}\right)$ was not considered in this paper since it was not comparable with measurements 


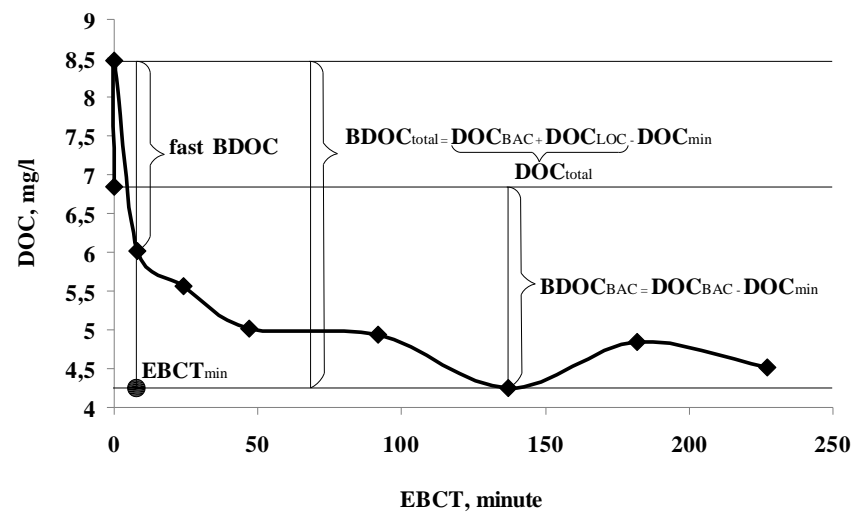

Figure 3. Principle of BDOC quantification shown on an example of $30 \mathrm{~h}$ feeding of BAC water sample supplemented with NaAc as a biostimulant.

of BDOC in WTP. The initial concentration of substrate in the BAC sample $\left(\mathrm{DOC}_{\mathrm{BAC}}\right)$ for the series of experiments with $\mathrm{NaAc}$ and LB was $5.87 \pm 0.96(n=9)$ and $4.73 \pm 0.19$ $(n=7) \mathrm{mg} \mathrm{l}^{-1}$, accordingly. For given DOC measurement this is variation of DOC measurements in inflow to the column during the all experiments due to natural variation of DOC in the BAC samples. The concentration of dose of biostimulant $\left(\mathrm{DOC}_{\mathrm{LOC}}\right)$ of $\mathrm{NaAc}$ and $\mathrm{LB}$ was $1.81 \pm 0.36(n=9)$ and $1.25 \pm 0.25(n=7) \mathrm{mg} \mathrm{l}^{-1}$, respectively.

The period of biodegradation time when $\mathrm{BDOC}_{\mathrm{BAC}}$ was $<15 \%$ in each water sample supplemented with LOC can be named an adaptation period of biomass (Tihomirova et al., 2012). During the adaptation period a decrease of minimal EBCT was observed (Table 1). The results showed that during the experiment the biodegradation rate constant using biostimulants NaAc and LB increased up to 41 and 26 times, respectively, and this time interval can be called the biostimulation period. The maximum concentration of BDOC and the maximum biodegradation rate was reached after 51 and $48 \mathrm{~h}$ feeding with NaAc and LB, respectively (Table 1). The biostimulation period with $\mathrm{NaAc}$ was accomplished after $53 \mathrm{~h}$, after which both $\mathrm{BDOC}_{\mathrm{BAC}}$ and biodegradation rate decreased. In water samples supplemented with LB the biostimulation period was accomplished after $168 \mathrm{~h}$. The removal efficiency of $\mathrm{BDOC}_{\mathrm{BAC}}$ reached up to $49 \%$ and $37 \%$ at maximal biodegradation rate with both $\mathrm{NaAc}$ and $\mathrm{LB}$, respectively which is significantly higher result compared with sample after BAC filters (Fig. 2). There was a strong positive correlation between biodegradation rate constant and $\mathrm{BDOC}_{\mathrm{BAC}}(r=0.63$ for NaAc; $r=0.65$ for LB; $P=0.6$ for both biostimulants). The biodegradation process can be divided in two periods - adaptation or coadaptation (20-24 h with biostimulants in this study) and biostimulation period, which was limited from 24 to $53 \mathrm{~h}$ for $\mathrm{NaAc}$ and from 20 to $168 \mathrm{~h}$ for LB biostimulant.

The experiments with BAC samples and $\mathrm{NaAc}$ and $\mathrm{LB}$ biostimulants showed that after the adaptation phase the fast degradable part increased to 28.9 and $29.3 \%$ of DOC, the slowly degradable increased to 20.9 and $10.7 \%$ and the nondegradable part decreased to 50.2 and $60 \%$, respectively (data not shown). The BDOC was 50 and $40 \%$ of DOC $_{\text {total }}$, respectively.

\section{Discussions}

Biostimulation approach was based on the hypothesis that the biodegradability in water samples is higher than the average concentration of BDOC measured at the effluent from BAC filters in WTP. This was concluded by Tihomirova (2011) over regular three year monitoring period of DOC and BDOC in WTP. The concentration of BDOC decreased from $1.47 \pm 1.05 \mathrm{mg} \mathrm{l}^{-1}$ in the raw water to $0.59 \pm 0.51 \mathrm{mg} \mathrm{l}^{-1}$ (10\% and $9 \%$ of the DOC, respectively) after rapid filter and increased to $0.82 \pm 0.38 \mathrm{mg} \mathrm{l}^{-1}(15 \%)$ after BAC filtration. High error range might be attributed to the fluctuation of raw water and treated water quality. Consequently, biological stability of water samples increased during coagulation-sedimentation and rapid sand filtration and ozonation, but it decreased again after BAC filters. DOC was higher in the river water than in the drinking water, but the ratio of BDOC/DOC $(\%)$ was higher in the drinking water $(15 \%)$. This indicate that after ozonation concentration of biodegradable organic compounds increased, but removal of biodegradable organic matter in biofilters or the production of biologically stable water is not efficient. Results of this study showed that average BDOC in BAC samples $(n=14)$ was $7 \%$ only.

The addition of LOC was related to time of adaptation of biomass in glass column system which for NaAc and LB biostimulants was 24 and $20 \mathrm{~h}$, respectively (Table 1) (Tihomirova et al., 2012), the time interval during which the BDOC value was negligible or biodegradation is not detected (Wiggins and Alexander, 1988). As shown previously (Yavich et al., 2004), the addition of a small amount of biostimulant resulted in an increase in BDOC concentration and a sharper decrease in "fast" BDOC.

As shown in this study for samples taken at Daugava WTP the biodegradation rate constant $\mathrm{k}$ of samples containing NaAc and LB as biostimulants increased up to 26 times compared with the BAC sample without biostimulant. Thus the biodegradation rates can be enhanced by using biostimulants.

According to obtained measurements in this study and recalculation biomass concentration was $806 \mathrm{ng}$ ATP per $\mathrm{cm}^{3}$ in experimental system. As shown previously (MagicKnezev and Van der Kooij, 2004), ATP concentration can ranged 25 to $5000 \mathrm{ng}$ ATP per $\mathrm{cm}^{3}$ in biofilters at different WTP. The results (Table 1) showed that biomass concentration detached from biofilter when biodegradation process was completed and decrease of biodegradation rate constant. Recalculated total biomass amount in system 
Table 1. Biodegradation of substrate in glass column system feed using water samples supplemented with labile organic carbon depending on the adaptation time of the experimental system.

\begin{tabular}{|c|c|c|c|c|c|c|c|c|}
\hline \multirow{2}{*}{$\begin{array}{l}\text { Adaptation } \\
\text { time, } \mathrm{h}\end{array}$} & \multicolumn{4}{|c|}{$\mathrm{BAC}+\mathrm{NaAc}$} & \multicolumn{4}{|c|}{$\mathrm{BAC}+\mathrm{LB}$} \\
\hline & $\begin{array}{l}\mathrm{EBCT}_{\text {min }}, \\
\min \end{array}$ & $\begin{array}{l}k \times 10^{-2} \\
\min ^{-1}\end{array}$ & $\begin{array}{l}\mathrm{BDOC}_{\mathrm{BAC}}, \\
\%\end{array}$ & $\begin{array}{l}\text { ATP, } \\
\text { cells } \\
\times 10^{8} \mathrm{ml}^{-1}\end{array}$ & $\begin{array}{l}\mathrm{EBCT}_{\text {min }}, \\
\text { min }\end{array}$ & $\begin{array}{l}k \times 10^{-2} \\
\min ^{-1}\end{array}$ & $\begin{array}{l}\mathrm{BDOC}_{\mathrm{BAC}}, \\
\%\end{array}$ & $\begin{array}{l}\text { ATP, } \\
\text { cells } \\
\times 10^{8} \mathrm{ml}^{-1}\end{array}$ \\
\hline 0 & $>272$ & 0 & 0 & 60 & $>272$ & 0.31 & 0.4 & 394 \\
\hline 4 & $>272$ & 0 & 0 & 26 & $>272$ & 0.41 & 2 & 412 \\
\hline 20 & - & - & - & - & 137 & 0.33 & 20 & 333 \\
\hline 24 & 272 & 0.18 & 27 & 52 & - & - & - & - \\
\hline 30 & 137 & 0.19 & 38 & 65 & - & - & - & - \\
\hline 44 & - & - & - & - & 47 & 1.30 & 27 & 291 \\
\hline 48 & 24 & 3.22 & 34 & 65 & 24 & 2.57 & 37 & 419 \\
\hline 51 & 24 & 4.16 & 49 & 49 & - & - & - & - \\
\hline 53 & 8 & 3.70 & 20 & 65 & - & - & - & - \\
\hline 168 & - & - & - & - & 272 & 0.18 & 30 & 552 \\
\hline 192 & 47 & 0.53 & 6 & 105 & 227 & 0.11 & 10 & 656 \\
\hline 240 & 92 & 0.25 & 1 & 1602 & - & - & - & - \\
\hline
\end{tabular}

Legends: the minimal EBCT $\left(\mathrm{EBCT}_{\min }\right)$, biodegradation rate constant $(k)$, concentration of $\mathrm{BDOC}(\%)$ and biomass concentration $($ determined as ATP, cell per ml) in effluent are shown.

was $405170 \mathrm{ng}$ ATP, and max detached biomass amount -33640 ng ATP, what is $8 \%$ of total biomass concentration in system. There was not significant correlation between cell concentration in the effluent and the ATP concentrations in the biofilter. These results showed that bacterial release into the effluent sample may be due to substrate concentration limitation after biodegradation.

The rate of biodegradation is highly variable and depends on many parameters including chemical structure and concentration of the organic substance in water samples, applied oxidant (ozone, chlorine) dose, temperature, salinity, $\mathrm{pH}$, concentration of oxygen, and inorganic nutrients and concentration of active microorganisms (Becker et al., 2006; Brandt et al., 2003, 2004; Kulp et al., 2007; Sanchez et al., 2007; Spain et al., 1980; Spain and Veld, 1983; Steiner and Sauer, 2001; Swindoll et al., 1988). Some organic compounds, especially aromatic compounds are rather resistant to natural biodegradation and biodegradation of a compound of the mixture can be strongly influenced by the presence of other components in the mixture (Tsai and Juang, 2006). It has been shown previously that the addition of LOC results in an increase of the concentration of easy degradable part of mixture and the stimulated biodegradation results in decrease in minimum EBCT compared to that without biostimulation (Spain et al., 1980; Yavich et al., 2004). The biodegradable DOC was utilized after short contact time or at the top of the biofilter (Moll et al., 1998). Direct addition of a nutrient can stimulate the activity of microbial communities (Macbeth et al., 2004) and the presence of easy degradable carbon sources can enhance the biodegradation of more persistent compounds (Brandt et al., 2003; Shimp and Pfaender, 1987).
Method of co-adaptation and its impact on the biodegradation of different chemicals has been used to degrade resistant chemical pollutions in different environmental settings (Schmidt and Alexander, 1985; Shimp and Pfaender, 1987; Wiggins and Alexander, 1988). Biostimulation method described in this study can also be compared with the other (e.g. phosphorus dosing into biofilters to stimulate the activity of the biomass, Rubulis, 2006).

Addition of biostimulant increased $\mathrm{BDOC}_{\text {total }}$ in influent water; however increase in the total consumption of BDOC allowed to reduce both BDOC added as biostimulant and native BDOC in the sample. In this study biostimulants (NaAc or LB) are easy convertible substrate for bacterial biomass. In these experiments $\mathrm{NaAc}$ was used as single carbon source and LB medium as multicarbon source. Results obtained in this study showed that BDOC concentration increased significantly and was utilized after 24 min contact time due to biostimulation comparing with sample without biostimulant.

This study showed that the biofiltration systems of the WTPs in Boreal regions treating humic rich water can be improved and with biostimulation approach biodegradation of humic rich water can reach up to $29 \%$, which is very close to the theoretical $-30 \%$ as DOC (Volk et al., 2002). LOC addition stimulated biodegradation rate of slowly biodegradable organic matter. The biomass consumed easy degradable substrate and the adaptation period contributed to that slowly degradable organic matter was used faster as a secondary substrate. From the results it can be concluded that LOC can be used as a stimulator of biodegradation which would allow to effective remove of slowly degradable organic matter within EBCT which is usually about $30 \mathrm{~min}$. The biostimulation period is the period limited in time when 
BDOC and the biodegradation rate constant substantially increase.

This study demonstrates principle of biostimulation applicability for enhanced DOC removal in drinking water technology. Before implementation in real plant the technology should be engineered to avoid both problems with release of biomass and other problems, which can related to optimal condition for filter operations such as application of automatic control of biomass and substrate dosing. In practice the optimal concentration of LOC would be depended from the DOC concentration in influent water. LOC work as stimulator, and to avoid the increase the BDOC in system after biofilter, LOC concentration should be verified for every individual plant.

\section{Conclusions}

From the obtained results it can be concluded that:

- The addition of LOC was related to the increase of the $\mathrm{DOC}_{\text {total }}$. At the same time $\mathrm{BDOC}_{\text {total }}$ increased significantly (up to 7 and 5 times higher with $\mathrm{NaAc}$ and LB as biostimulants, respectively) and it was utilized after 24 min contact time due to biostimulation.

- The study demonstrates that biodegradation rates can be increased by using a biostimulant. The biodegradation rates of BDOC in BAC water samples with $\mathrm{NaAc}$ and $\mathrm{LB}$ as biostimulants were $4.16 \times 10^{-2}$ and $2.57 \times 10^{-2} \mathrm{~min}^{-1}$ whereas the degradation rate in the sample without biostimulant was $0.10 \times 10^{-2} \mathrm{~min}^{-1}$.

- There was a strong positive correlation between the constant of biodegradation rate and $\mathrm{BDOC}_{\mathrm{BAC}}(r=0.63$ for NaAc; $r=0.65$ for LB; $P=0.6$ for both biostimulants).

- The adaptation time for the mixture of sample and biostimulant was 20 and $24 \mathrm{~h}$ for LB and $\mathrm{NaAc}$, respectively.

- The biostimulation period for NaAc and LB biostimulants was from 24 to $53 \mathrm{~h}$, and from 20 to $168 \mathrm{~h}$, respectively.

- The biostimulation period was accomplished with increasing EBCT, decreasing BDOC and biomass detachment.

Acknowledgements. This work has been partly supported by the European Social Fund within the National Programme "Support for the carrying out doctoral study program's and post-doctoral researches" project "Support for the development of doctoral studies at Riga Technical University". This work has been undertaken as a part of the research project "Technology enabled universal access to safe water - TECHNEAU" (Nr. 018320) which is supported by the European Union within the 6th Framework Programme. There hereby follows a disclaimer stating that the authors are solely responsible for the work. It does not represent the opinion of the Community and the Community is not responsible for any use that might be made of data appearing herein.

Edited by: P. Le-Clech

\section{References}

Becker, J. G., Berardesco, G., Rittmann, B. E., and Stahl, D. A.: Effects of endogenous substrate on adaptation of anaerobic microbial communities to 3-Chlorobenzoate, Appl. Environ. Microbiol., 72, 449-456, 2006.

Berney, M., Weilenmann, H. U., and Egli, T.: Flow-cytometric study of vital cellular functions in Escherichia coli during solar disinfection (SODIS), Microbiology, 152, 1719-1729, 2006.

Brandt, B. W., Van Leeuwen, I. M. M., and Kooijman, S. A. L. M.: A general model for multiple substrate biodegradation. Application to co-metabolism of structurally non-analogous compounds, Water Res., 37, 4843-4854, 2003.

Brandt, B. W., Kelpin, F. D. L., Van Leeuwen, I. M. M., and Kooijman, S. A. L. M.: Modeling microbial adaptation to changing availability of substrates, Water Res., 38, 1003-1013, 2004.

Carlson, K. H. and Amy, G. L. Ozone and biofiltration for multiple objectives, J. Am. Water Works Assoc., 93, 88-98, 2001.

Eikebrokk, B., Juhna, T., Melin, E., and Osterhus, S. W.: Deliverable 5.3.2a. Water Treatment by Enhanced Coagulation and Ozonation-Biofiltration. Intermediate report on operation optimization procedures and trials. Report of Integrated Project TECHNEAU Funded by the European Commission under the Sustainable Development, Global Change and Ecosystems Thematic Priority Area, http://www.techneau.org/index.php?id=120, last access: 12 August 2009, 2007.

European Standard EN 1484:1997: Water analysis - Guidelines for the determination of total organic carbon (TOC) and dissolved organic carbon (DOC), 1997.

Fahmi, Nishijima, W., and Okada, O.: Improvement of DOC removal by multi-stage AOP-biologycal treatment, Chemosphere, 50, 1043-1048, 2003.

Fower, J., Cohen, L., and Jarvis, P.: Practical Statistics for field biology, 1st Edn., John Wiley \& Sons Inc, USA, 1998.

Hammes, F. and Vital M.: Deliverable 3.3.9. A Report on the Growth of Pathogenic Bacteria on Natural Assimilable Organic Carbon. Report of Integrated Project TECHNEAU Funded by the European Commission under the Sustainable Development, Global Change and Ecosystems Thematic Priority Area, http: //www.techneau.org/index.php?id=120, last access: 17 August 2009, 2008.

Huck, P. M.: Measurement of biodegradable organic matter and bacterial growth in drinking water, J. Am. Water Works Assoc., 82, 121-132, 1990.

Kaplan, L. A., Reasoner, D. J., and Rice, E. W.: A survey of BOM in United-Satates drinking waters, J. Am. Water Works Assoc., 86, 78-86, 1994.

Klevens, C. M., Collins, M. R., Negm, R., and Farrar, M. F.: Characterization of NOM removal by biological activated carbon, in: Advances in Slow Sand and Alternative Biological Filtration, edited by: Graham, N. and Collins, R., John Wiley \& Sons, 7987, 1996 
Kulp, T. R., Han, S., Saltikow, C. W., Lanoil, B. D., Zargar, K., and Oremland, R. S.: Effect of imposed salinity gradients on dissimilatory arsenate reduction, sulphate reduction, and other microbial processes in sediments from two California soda lakes, Appl. Environ. Microbiol., 73, 5130-5137, 2007.

Macbeth, T. W., Cummings, D. E., Spring, S., Petzke, L. M., and Sorenson, K. S.: Molecular characterization of a dechlorinating community resulting from in situ biostimulation in trichlororthene-contaminated deep, fractured basalt aquifer and comparison to a derivative laboratory culture, Appl. Environ. Microbiol., 70, 7329-7341, 2004.

Magic-Knezev, A. and Van der Kooij, D.: Optimization and significance of ATP analysis for active biomass in granular activated carbon filters used in water treatment, Water Res., 38, 39713979, 2004.

Miettinen, I. T., Vartiainen, T. K., and Martikainen, P. J.: Determination of assimilable organic carbon (AOC) in humus-rich waters, Water Res., 33, 2277-2282, 1999.

Moll, D. M., Summers, R. S., and Breen, N.: Microbial characterization of biological filters used for drinking water treatment, Appl. Environ. Microbiol., 64, 2755-2759, 1998.

Ribas, F., Frias, J., and Lucena, F.: A new dynamic method for the rapid determination of the biodegradable dissolved organic carbon in drinking water, J. Appl. Microbiol., 71, 371-378, 1991.

Rubulis, J.: The influence of phosphorus on the formation of biofilm in drinking water, Ph.D. thesis, Riga Technical University, Riga, Latvia, 2006.

Sanchez, B., Champomier-Verges, M.-C., Collado, C., Anglade, P., Baraige, F., Sanz, Y., De Los Reyes-Gavilan, C. G., Margolles, A., and Zagorec, M.: Low-pH adaptation and the acid tolerance response of Bifidobacterium longum biotype longum, Appl. Environ. Microbiol., 73, 6450-6459, 2007.

Schmidt, S. K. and Alexander, M.: Effect of dissolved organic carbon and second substrates on the biodegradation of organic compounds at low concentrations, Appl. Environ. Microbiol., 49, 822-827, 1985.

Shimp, R. J. and Pfaender, F. K.: Effect of adaptation to phenol on biodegradation of monosubstituted phenols by aquatic microbial communities, Appl. Environ. Microbiol., 53, 1496-1499, 1987.

Spain, J. C. and Veld, P. A. V.: Adaptation of natural microbial communities to degradation of xenobiotic compounds: effects of concentration, exposure time, inoculum, and chemical structure, Appl. Environ. Microbiol., 45, 428-435, 1983.

Spain, J. C., Pritchard, P. H., and Bourguin, A. W.: Effect of adaptation on biodegradation rates in sediments/water cores from Estuarine and freshwater environments, Appl. Environ. Microbiol., 40, 726-734, 1980.
Steiner, P. and Sauer, U.: Proteins induced during adaptation of Acetobacter aceti to high acetate concentrations, Appl. Environ. Microbiol., 67, 5474-5481, 2001.

Swindoll, C. M., Aelion, C. M., and Pfaender, F. K.: Influence of inorganic and organic nutrients on aerobic biodegradation and adaptation response of subsurface microbial communities, Appl. Environ. Microbiol., 54, 212-217, 1988.

Tihomirova, K.: NOM Removal from Water and its Influence on the Drinking Water Quality: Natural organic matter removal from water and its influence on the water quality in distribution network, LAP LAMBERT Academic Publishing, ISBN: 978-38465-2340-7, 172 pp., 2011.

Tihomirova, K., Rubulis, J., and Juhna, T.: Changes of NOM Fractions during conventional drinking water treatment process in Riga, Latvia, Wa. Sci. Technol., 10, 157-163, doi:10.2166/ws.2010.652, 2010.

Tihomirova, K., Briedis, A., Rubulis, J., and Juhna, T.: Effect of biomass adaptation to biodegradation of dissolved organic carbon in water, Biodegradation, 23, 319-324, doi:10.1007/s10532011-9511-z, 2012.

Tsai, S.-Y. and Juang, R.-S.: Biodegradation of phenol and sodium salicylate mixtures by suspended Pseudomona Putilda CCRC 14365, J. Hazard. Mater., 138, 125-132, 2006.

Van der Kooij, D., Visser, A., and Hijnen, W. A. M.: Determination the concentration of easily assimilable organic carbon in drinking water, J. Am. Water Works Assoc., 74, 540-545, 1982.

Volk, C., Wood, L., Johnson, B., Robinson, J., and Kaplan, L.: Monitoring dissolved organic carbon in surface and drinking water, J. Environ. Monit., 4, 43-47, 2002.

Volk, L., Renner, C., Roche, P., Paillard, H., and Joret, J. C.: Effects of ozone on the production of biodegradable dissolved organic carbon (BDOC) during water treatment, Ozone: Sci. Eng., 15, 389-404, 1993.

Wiggins, A. B. and Alexander, M.: Role of chemical concentration and second carbon sources in acclimation of microbial communities for biodegradation, Appl. Environ. Microbiol., 54, 28032807, 1988.

Yavich, A. A., Lee, K.-H., Chen, K.-C., Pape, L., and Masten, S. J.: Evaluation of biodegradability of NOM after ozonation, Water Res., 38, 2839-2846, 2004. 